\title{
Study on the Adaptation of Superior and Local Upland Rice Varieties (Oriza sativa) in Dry Climate of West Southeast Moluccas Border Region of Country
}

\author{
Sheny S. Kaihatu, Wahid, Edwen D. Waas \\ Researches of Assessment Institute for Agricultural Technology of Moluccas, Jln Chr. \\ Soplanit Rumah Tiga Ambon, Indonesia \\ Marthen P. Sirappa (Coresponding Author) \\ Researches of Assessment Institute for Agricultural Technology of West Sulawesi, Kompleks \\ Perkantoran Pemerintah Provinsi Sulawesi Barat, Jln H. Abdul Malik Pattana Endeng, \\ Mamuju, Sulawesi Barat, Indonesia, E-mail: mpsirappa@gmail.com
}

Received: Feb. 17, 2019 Accepted: Mar. 19, 2019 Published: Mar. 26, 2019

doi:10.5296/jas.v7i1.14565

URL: https://doi.org/10.5296/jas.v7i1.14565

\begin{abstract}
This study on the adaptation of superior and local upland rice on dry climate was carried out from July to October 2017 at the West Southeast Moluccas Main Seed Center involving 15 members of the Webat Farmer Groups. The aim of this study was to obtain adaptive superior and local varieties that could potentially be developed in dry climates (dry land) in the region. Field assessments were done usinged a Randomized Block Design with eight treatments (superior and local varieties of upland rice) and repeated three times. The five superior varieties assessed were Towuti, Inpago 8, Inpago 9, Inpago 10, and Inpago 11 and the three local varieties used were Red Tanimbar, White Tanimbar, and Black Tanimbar. The results of the study showed that the average productivity of superior new varieties of upland rice higher yields $\left(2.03 \mathrm{t} \mathrm{ha}^{-1}\right)$ compared to local varieties $\left(1.24 \mathrm{t} \mathrm{ha}^{-1}\right)$, revealing a yield increase of $63.71 \%$. Results suggest that there are five varieties of upland rice that have potential to be developed in the West Southeast Moluccas Border Region, namely Inpago 9, Inpago 10, and Inpago 11 (superior new varieties), and Red Tanimbar and White Tanimbar (local varieties). However, the yields obtained in this assessment are still low because the number of productive tillers is also low. This could be due to low plant density caused by the very small number of seeds used per planting hole, and the effect of legowo 2: 1 planting system with a very wide.
\end{abstract}

Keywords: adaptation, rice varieties, dry land, dry climate 


\section{Introduction}

Upland rice has the potential to support increased national rice production. The presence of upland rice is an optimization solution for dry land. The main obstacle in upland rice cultivation is the limited availability of water because it depends on the intensity, rainfall distribution and number of rainy days. According to Supijatmo et al. (2012) the scarcity of water availability is one of the serious problems faced in the rice production system. This problem arises because of climate change and rainfall patterns. Therefore, land for upland rice cultivation is only used once a year (Manurung et al. 2017). The Moluccas Province is concerned with this limitation. It has three district areas which are border areas, namely; (1) West Southeast Moluccas Regency borders Australia and Timor Leste, (2) Aru Islands Regency which is directly adjacent to Australia, and (3) Southwest Moluccas Regency which is directly adjacent to Timor Leste (Anonymous 2018). The three districts are one of the border regions that have low economic growth, including the agricultural sector. In order to accelerate the agricultural development process, an integrated and comprehensive approach is needed, covering the technical aspects of biophysics and technology, economics, social culture, and politics. Problems that are often faced by border areas include isolation, underdevelopment, poverty, and the limitations of public service infrastructure and facilities, especially physical and institutional infrastructure. In addition, the uneven distribution of the population and the low quality of human resources also hamper regional development in an integrated manner.

Potential land availability for the development of dryland agriculture (including upland rice) in the border area of West Southeast Moluccas district was 455,281 ha consisting of agroforestry (70,598 ha) with a slope of $9 \%-15 \%$ and lowland (384,683 ha) with slope 3\% $8 \%$ (Susanto \& Bustaman 2006), but only a small portion of 2,238 ha $(0.51 \%)$ is used, So that the opportunity for extensification development is still wide open for 440,618 ha or around $99.49 \%$ of potential land. Likewise the potential for increased production is quite large, because the productivity achieved at the farm level is still relatively low. Based on data from Central Bureau of Statistic (CBS) of the Moluccas Province (CBS 2015), the average field rice productivity between 2011 and 2015 in Moluccas is still relatively low ( $2.62 \mathrm{t} \mathrm{ha}^{-1}$ ) while the yield potential can reach $8.0 \mathrm{t} \mathrm{ha}^{-1}$ (Jamil et al. 2015) with the application of innovative technology.

Reasons for the low productivity of paddy fields at the farm level are sub-optimal conditions such as drought and nutrient deficiency, and the quality of varieties used. So far the varieties commonly used by farmers are varieties that have been planted for generations with a limited amount. According to Saylendra (2010), high-quality seeds can produce plants that are healthy and grow uniformly. Pringadi et al. (2001) in Wahyuni (2008) also stated that most farmers still plant local varieties of upland rice with non-optimal cultivation techniques. It has been reported that there are several upland rice superior varieties from the IAARD that have high yield potential and are tolerant of suboptimal conditions (Suprihatno et al. 2011 in Yuniarti 2015). With the use of superior varieties, optimal cultivation techniques, and good disease control, upland rice productivity can reach $5.4 \mathrm{t}-6.8 \mathrm{t} \mathrm{ha}^{-1}$ (Guswara et al. 1998 in Wahyuni 2008). Even new superior varieties released lately have yield potential of $5.6 \mathrm{t}-8.4 \mathrm{t} \mathrm{ha}^{-1}$ (Jamil et al. 2015). 
Between 1994 and 2016, many superior upland rice varieties ( \pm 22 varieties) were released by the IAARD, including Cirata, Towuti, Limboto, Danau Gaung, Batu Tegi, Situ Patenggang, Situ Bagendit, Inpago 4, Inpago 5, Inpago 6, Inpago 7, Inpago 8, Inpago 9, Inpago 10, Inpago Lipigo 4, and Inpago 11 Agritan (Jamil et al. 2015 in Nuryanto 2018). In general, these varieties are early maturing 105-119 days, $100-124 \mathrm{~cm}$ high, tolerant of aluminum poisoning, drought tolerant, resistant to several types of blast disease, with a yield potential of $6 \mathrm{t}-8 \mathrm{t}$ $\mathrm{ha}^{-1}$ and suitable for cultivation on low lands dry land $<500 \mathrm{~m}$ above sea level (asl). These superior varieties need to be evaluated in order to determine which varieties are suitable for development in upland rice planting areas.

Considering that multilocation test of food crops in the framework of releasing superior varieties has never been carried out in Moluccas province, the potential yields of local upland rice have not yet been identified, so a study of adaptation of superior varieties (new and local varieties) is needed to be developed in the West Southeast Moluccas border region.

The aim of this study was to obtain adaptive superior varieties that have the potential to be developed in dry climates on dry land in the West Southeast Moluccas border region.

\section{Methodology}

The assessment was carried out on the Main Seed Hall (MSH) field of Wesawak Village, South Tanimbar Sub-District, Southeast West Moluccas Regency, classified as dry climate dry land low lands with a height of $101 \mathrm{~m}$ asl and located at the ordinate points: SL (South Latitude): - 7051'24 "and EL (East Longitude): 131016'52". The assessment was conducted from July to October 2017 and involving 15 members of the Webat Farmer Group, Wesawak village, South Tanimbar sub-district, West Southeast Moluccas.

The study used a randomized block design with 8 (eight) varieties as a treatment and each treatment was repeated 3 (three) times. The treatment consisted of five new superior varieties (Inpago 8; Inpago 9; Inpago 10; Inpago 11; and Towuti) and three local superior varieties (Red Tanimbar, White Tanimbar and Black Tanimbar. Each treatment was made of plots measuring $3 \mathrm{~m}$ x $5 \mathrm{~m}$. Planting was carried out in a jajar legowo 2:1 $(30 \mathrm{~cm} \times 15 \mathrm{~cm}) \times 60 \mathrm{~cm}$ system, in an area of 0.5 ha by planting 1-2 seeds/planting holes. Balanced fertilization with a dosage of $200 \mathrm{~kg}$ Urea and $400 \mathrm{~kg}$ NPK Phonska (15:15:15) was carried out in an array. The application of fertilizer was done twice, 10 days after planting (dap) with a measure of $1 / 3$ Urea+2/3 NPK and at 30 days with dosage 2/3 urea+1/3 NPK Phonska. Control of stem borers was done by using Furadan $3 \mathrm{G}$ at a rate of $30 \mathrm{~kg} \mathrm{ha}^{-1}$ per application mixed with fertilizer.

The variables observed included: 1) growth component: plant height at harvest and number of tillers (maximum and productive); 2) yield components: panicle length, number of filled grains per panicle, percentage of empty grain per panicle, number of filled grains, number of empty grains, dry grain grain weight per clump, weighing 1,000 dry seeds; 3) yield of harvested dry grain per plot of harvest (conversion to hectares).

The variables of growth components and yield components were observed for 10 sample plants per plot which were randomly determined, while the results of dry grain harvesting and 
observation of pests were observed in sample plots (size) with a size of $2 \mathrm{~m} \mathrm{x} 3 \mathrm{~m}=6 \mathrm{~m}^{2}$.

Data analysis was done using statistical methods, consisting of analysis of variance/Annova (F-Test) to determine the effect of treatment and t-test (DMRT) to see the effect between treatments tested using the procedure by Gomez \& Gomez (1995).

\section{Results and Discussion}

\subsection{Geographical Circumstances}

West Southeast Moluccas Regency has a geographical position bordering neighboring countries such as Australia and Timor Leste, located at coordinates 6030'24 "- 8024'36" SL (South Latitude) and 130037'47 "- 13004'12" EL (East Longitude).

Geographically, Southeast West Moluccas Regency is limited by:

- South Side: East Sea and Pacific Ocean

- North Side: Banda Sea

- East Side: Arafura Sea

- West Side: Babar Sermatang Island Group

West Southeast Moluccas Regency is a division of Southeast Moluccas Regency, formed based on Law No. 46 of 1999. This regency is an archipelago district with a land area of \pm $10,102.92 \mathrm{~km}^{2}(19.06 \%)$ and an area of ocean $\pm 42,892.28 \mathrm{~km}^{2}(80.94 \%)$ of the West Southeast Moluccas area. According to Ralahalu (2007), the Southeast West Moluccas plains region consists of four archipelago groups, namely: (1) Covert Islands Group (area 4,686 $\mathrm{km}^{2}$ ), (2) Lemola Islands Cluster (area 1,506 km²), (3) Babar Islands Cluster (area of 2,456 $\mathrm{km}^{2}$ ), and (4) Tanimbar Islands Cluster (area of 5,936 $\mathrm{km}^{2}$ ).

The morphology of this area can be divided into 3 units, namely hills (> $300 \mathrm{~m}$ asl), lowlands following watersheds and terraces/steps are in a number of small islands which are limited by steep slopes but almost flat peaks with the highest peak of $104 \mathrm{~m}$.

The climate in the West Southeast Moluccas Regency is strongly influenced by the seasonal wind circulation that moves from the equatorial direction so that the climate pattern in the West Southeast Moluccas Regency is an equatorial pattern characterized by the form of bimodal rain patterns (two peaks of rain) namely December/January and April/May. The average temperature ranges from $25.6^{\circ} \mathrm{C}-28.9^{\circ} \mathrm{C}$.

\subsection{Component of Growth}

Plant growth is a process in plants which results in changes in the size of the plant getting bigger. Plant height is a measure that is often observed as an indicator of growth and as a parameter used to measure the influence of the type of treatment and as a characteristic that determines plant production and is closely related to photosynthesis.

The components of growth observed include plant height and number of tillers (calcium and productive), can be seen in Table 1. Table 1, shows that superior local field rice plants have 
significantly higher plant growth compared to New Superior Varieties (NSV) rice fields. However, local superior varieties have a number of tillers (maximum and productive) that are significantly lower than the new superior varieties. The highest plant height $(114.97 \mathrm{~cm})$ was achieved by the local Black Tanimbar variety and was not significantly different from the local White Tanimbar and Red Tanimbar varieties. In contrast, the new superior varieties of Towuti gave the lowest plant height $(44.33 \mathrm{~cm})$ and were not significantly different from new superior varieties Inpago 9 and Inpago 10 (Table 1).

In this study both new superior varieties and local superior varieties have lower plant height compared to their morphological characters. This is due to drought during the plant growth phase (from planting to harvesting monthly rainfall $<200 \mathrm{~m}$ ). According to Sumarno \& Hidayat (2007) upland rice cultivation requires rainfall above $200 \mathrm{~mm} / \mathrm{month}$ which lasts sequentially for at least 4 months. The height of the plant besides being influenced by genetic traits is also influenced by the environmental conditions of growing plants. Associated with plant height, farmers prefer plants with plant heights that are not too high. This is related to the level of resistance of plants to weather conditions such as rain and wind, where plants with higher height easy fall down.

The more planted population on a land, the faster the plant growth because plants try to find more sunlight (Nursanti 2009 in Sitinjak \& Idwar 2015). Suprihatno (2010) in Haryati \& Liferdi (2017) states that high and low stems of plants are influenced by characteristics or characteristics that affect the yield power of varieties. Growth in plant height varies from each variety due to genetic factors and plant environmental conditions (Sujitno et al. 2011).

The highest maximum number of tillers (18.47) was achieved by Inpago 8 and not significantly different from Inpago 9 and Towuti, while the local superior varieties of Red Tanimbar gave the least number of maximum tillers (10.80) but were not significantly different from White Tanimbar (10.93), Black Tanimbar (12.07), Inpago 10 (15.40), and Inpago 11 (15.67) tillers.

The new superior variety Inpago 10 also had the highest number of productive tillers (8.52) and wss significantly different from Inpago 9, Inpago 11, and Towuti. On the contrary, local superior varieties had the lowest number of tillers (maximum and productive) compared to other superior varieties (Table 1). 
Table 1. Average Plant Height and Number of Tillers (Maximum and Productive) on Dry Climate Dry Land in Southeast West Moluccas Border Region, 2017.

\begin{tabular}{lccc}
\hline Varieties & Plant High & \multicolumn{2}{c}{ Number of tillers } \\
\cline { 3 - 4 } & $(\mathrm{cm})$ & Maximum & Productive \\
\hline Inpago 8 & $78.60 \mathrm{~b}$ & $18.47 \mathrm{a}$ & $6.33 \mathrm{bc}$ \\
Inpago 9 & $65.73 \mathrm{bc}$ & $15.87 \mathrm{a}$ & $7.70 \mathrm{ab}$ \\
Inpago 10 & $66.33 \mathrm{bc}$ & $15.40 \mathrm{~b}$ & $8.52 \mathrm{a}$ \\
Inpago 11 & $80.80 \mathrm{~b}$ & $15.67 \mathrm{~b}$ & $7.56 \mathrm{ab}$ \\
Towuti & $44.33 \mathrm{c}$ & $17.53 \mathrm{a}$ & $7.85 \mathrm{ab}$ \\
Red Tanimbar & $104.47 \mathrm{a}$ & $10.80 \mathrm{~b}$ & $4.93 \mathrm{c}$ \\
White Tanimbar & $108.60 \mathrm{a}$ & $10.93 \mathrm{~b}$ & $4.85 \mathrm{c}$ \\
Black Tanimbar & $114.97 \mathrm{a}$ & $12.07 \mathrm{~b}$ & $3.93 \mathrm{c}$ \\
\hline CV $(\%)$ & 2.09 & 1.58 & 2.06 \\
\hline
\end{tabular}

Remarks: The same letters in the same column and treatment group mean that they are not significantly different at the 0.05 level

\subsection{Component of Yield}

Components of yield observed included panicle length, number of panicle containing per clump, percentage of hollow panicles per clump, number of filled grains per panicle, percentage of grain per panicle, weight of milled dry grain per plant, and weight of 1,000 grains, as presented in Table 2.

Table 2. Average Components of Yield of Adaptation to Field Rice Superior Variety on Dry Climate Dry Land in Southeast West Moluccas Border Region, 2017

\begin{tabular}{|c|c|c|c|c|c|c|c|}
\hline Varieties & $\begin{array}{c}\text { Panicle } \\
\text { Length } \\
(\mathrm{cm})\end{array}$ & $\begin{array}{l}\text { Number } \\
\text { of } \\
\text { Panicles } \\
\text { per } \\
\text { Clump }\end{array}$ & $\begin{array}{c}\text { Percentage } \\
\text { of Hallow } \\
\text { Panicle } \\
\text { per } \\
\text { Clump }(\%)\end{array}$ & $\begin{array}{c}\text { Number } \\
\text { of Filled } \\
\text { Grains } \\
\text { perPanicle }\end{array}$ & $\begin{array}{c}\text { Percentage } \\
\text { of Grain } \\
\text { per } \\
\text { Panicle }(\%)\end{array}$ & $\begin{array}{l}\text { Weight of } \\
\text { Filled } \\
\text { Grain per } \\
\text { Panicle(g) }\end{array}$ & $\begin{array}{c}\text { Weight } \\
\text { of } 1,000 \\
\text { grains }(\mathrm{g})\end{array}$ \\
\hline Inpago 8 & $23.22 \mathrm{a}$ & $6.33 \mathrm{ab}$ & $8.25 \mathrm{~d}$ & $53.39 b c$ & $28.27 \mathrm{abc}$ & $6,90 \mathrm{~b}$ & $24.47 b$ \\
\hline Inpago 9 & $20.39 b c$ & $7.78 \mathrm{a}$ & $6.55 \mathrm{~d}$ & $74.56 \mathrm{a}$ & $38.55 \mathrm{ab}$ & $8.08 \mathrm{a}$ & $24.45 b$ \\
\hline Inpago10 & $19.58 b$ & $8.22 \mathrm{a}$ & $9.61 \mathrm{~d}$ & $84.11 \mathrm{a}$ & $33.00 \mathrm{ab}$ & $8.23 \mathrm{ab}$ & $24.57 b$ \\
\hline Inpago11 & $24.39 \mathrm{a}$ & $7.56 \mathrm{ab}$ & $7.82 \mathrm{~d}$ & $58.55 \mathrm{~b}$ & $36.96 \mathrm{ab}$ & $7.49 \mathrm{a}$ & $25.10 \mathrm{~b}$ \\
\hline Towuti & $20.00 b c$ & $7.67 \mathrm{ab}$ & $21.67 \mathrm{ab}$ & $57.89 \mathrm{~b}$ & $20.82 \mathrm{c}$ & $7.47 \mathrm{ab}$ & $26.25 \mathrm{a}$ \\
\hline $\begin{array}{l}\text { Red } \\
\text { Tanimbar }\end{array}$ & $24.41 \mathrm{a}$ & $5.44 \mathrm{bc}$ & $32.68 \mathrm{ab}$ & $48.22 b c$ & $36.90 \mathrm{ab}$ & $3.75 \mathrm{c}$ & $24.92 b$ \\
\hline $\begin{array}{l}\text { White } \\
\text { Tanimbar }\end{array}$ & $22.55 \mathrm{ab}$ & $4.89 \mathrm{c}$ & $33.05 \mathrm{ab}$ & $45.22 \mathrm{~cd}$ & $38.34 \mathrm{ab}$ & $3.96 \mathrm{c}$ & $24.68 b$ \\
\hline $\begin{array}{l}\text { Black } \\
\text { Tanimbar }\end{array}$ & $24.83 \mathrm{a}$ & $3.78 \mathrm{c}$ & $21.17 \mathrm{c}$ & $32.00 \mathrm{~d}$ & $39.61 \mathrm{a}$ & $3.43 \mathrm{c}$ & $24.75 b$ \\
\hline $\mathrm{CV}(\%)$ & 1.93 & 2.37 & 4.55 & 1.45 & 2.52 & 6.16 & 2.35 \\
\hline
\end{tabular}


Remarks: The same letters in the same column and treatment group mean that they are not significantly different at the 0.05 level

Table 2 shows that the rice fields of the local Black Tanimbar variety have the longest panicle length $(24.83 \mathrm{~cm})$ and are significantly different from other varieties except for the local Red Tanimbar $(24.41 \mathrm{~cm})$, Inpago $11(24.39 \mathrm{~cm})$, Inpago $8(23.22 \mathrm{~cm})$, and local White Tanimbar $(22.55 \mathrm{~cm})$. While Inpago 10 has the shortest panicle length $(19.58 \mathrm{~cm})$ and is not significantly different compared to Inpago 9, Towuti, and local variety of White Tanimbar $(22.55 \mathrm{~cm})$.

The highest number of panicles filled per clump (8.22) was achieved by Inpago 10 variety and not significantly different from other new superior varieties, but significantly different compared to local varieties (Red Tanimbar, White Tanimbar, and Black Tanimbar). Mean while the lowest number of panicles (3.78) was reached by the local Black Tanimbar variety and not significantly different with other local varieties compared to the new superior varieties, as shown in Table 2.

New superior varieties have the lowest percentage of hollow panicles per clump and the highest number of filled grains per panicle and are significantly different compared to local superior varieties (Table 2). Inpago 10 had the highest number of filled grains per panicle (84.11 grains) and was significantly different compared to Inpago 9 (74.56 grains). Whereas the local Black Tanimbar variety had fewer grains per panicle (32 grains) and was significantly different from White Tanimbar (45.22 grains). Towuti superior varieties had lower percentage grain per panicle $(20.82 \%)$ and were significantly different from all varieties tested, except for Inpago 8 variety (28.27\%) (Table 2).

Furthermore, Table 2 shows that the weight of milled dry grain (MDG) per plant was highest $(8.23 \mathrm{~g})$ for Inpago 10 variety and was not significantly different from Inpago 9 variety (8.08 g), Inpago $11(7.49 \mathrm{~g})$, and Towuti $(7.47 \mathrm{~g})$. Whereas the average local variety gave the weight of MDG per plant and was significantly lower than the new superior varieties. The local variety Black Tanimbar has the lowest milled dry grain weight per plant (3.43 g), following the Red Tanimbar (3.75 g), and White Tanimbar (3.96 g). The average weight of 1,000 grains was not significantly different between the varieties tested, except the superior varieties of Towuti which were significantly different and weighed the highest 1,000 grains (26.25 g) (Table 2).

\section{Yield of Milled Dry Grain}

Yield of milled dry grain per sample plot $\left(6 \mathrm{~m}^{2}\right)$ and yield of milled dry grain per hectare were observed, as presented in Table 3. Furthermore, Table 3 shows that the average new superior variety gave higher yields of milled dry grain per plot and per hectare, each of $1,216.8 \mathrm{~g}$ per $6 \mathrm{~m}^{2}$ and $2.03 \mathrm{t} \mathrm{ha}^{-1}$ compared to local superior varieties of $746 \mathrm{~g}$ per $6 \mathrm{~m}^{2}$ and $1.24 \mathrm{t} \mathrm{ha}^{-1}$, respectively. Thus an increase in productivity of new superior varieties was $63.09 \%$ when compared to local superior varieties. The highest yield of milled dry grain per hectare (productivity) was obtained by superior varieties of Inpago $10\left(2.15 \mathrm{t} \mathrm{ha}^{-1}\right)$ and significantly different compared to local superior varieties (Red Tanimbar, White Tanimbar, and Black Tanimbar), but not significantly different compared to new superior varieties, 
except for superior variety Inpago 8 which was significantly different (Table 3).

The new superior varieties Inpago 9, Inpago 10 and Inpago 11, and the local varieties Red Tanimbar and White Tanimbar have the potential to be developed in dry climates with dry land in the West Southeast Moluccas Border Region, since they provided the highest yields each i.e. $2.15 \mathrm{t} ; 2,12 \mathrm{t} ; 2.00 \mathrm{tha}^{-1}, 1.29 \mathrm{t}$ and $1.25 \mathrm{t}$ ha ${ }^{-1}$, respectively.

In this study, the productivity of grain is still low compared to the potential yield of some new superior varieties which can reach more than 5 tons per hectare. This was, due to the very small number of seeds used per planting hole, which affected the number of tillers, both tillers maximum or productive tillers. In addition to the small number of seeds per planting hole, the Legowo 2:1 planting system with a spacing that is too wide will affect the plant population per hectare. The reduced crop population will also reduce yield per hectare.

Table 3. Average yield of milled dry grain per sample plot and per hectare, 2017

\begin{tabular}{|c|c|c|}
\hline \multirow[t]{2}{*}{ Varieties } & \multicolumn{2}{|c|}{ Yield of Milled Dry Grain } \\
\hline & Sample Plot (g / $\left.6 \mathrm{~m}^{2}\right)$ & Hectare (ton) \\
\hline Inpago 8 & $1,128 \mathrm{~b}$ & $1.88 \mathrm{~b}$ \\
\hline Inpago 9 & $1,272 \mathrm{a}$ & $2.12 \mathrm{a}$ \\
\hline Inpago 10 & $1,290 \mathrm{a}$ & $2.15 \mathrm{a}$ \\
\hline Inpago 11 & $1,200 \mathrm{~b}$ & $2.00 \mathrm{a}$ \\
\hline Towuti & $1,194 \mathrm{ab}$ & $1.99 \mathrm{ab}$ \\
\hline $\begin{array}{c}\text { Average Superior } \\
\text { Varieties }\end{array}$ & $1,216,8$ & 2.03 \\
\hline Red Tanimbar & $774 \mathrm{bc}$ & $1.29 \mathrm{~b}$ \\
\hline White Tanimbar & $750 \mathrm{c}$ & $1.25 \mathrm{a}$ \\
\hline Black Tanimbar & $714 \mathrm{c}$ & $1.19 \mathrm{a}$ \\
\hline Average local Varieties & 746 & 1.24 \\
\hline $\mathrm{CV}(\%)$ & 8.15 & 8.15 \\
\hline
\end{tabular}

Remarks: The same letters in the same column and treatment group mean that they are not significantly different at the 0.05 level 


\section{Conclusion}

Results of this study suggest that the new superior varieties of Inpago 9, Inpago 10 and Inpago 11 have the potential to be developed in dry climates with dry land in the Southeast West Moluccas Border Region, since they provided the highest yields each 2.15 t; $2,12 \mathrm{t}$; and $2.00 \mathrm{t} \mathrm{ha}^{-1}$, respectively. The local varieties, Red Tanimbar and White Tanimbar have the potential to be developed as local superior varieties in dry climate with dry land in the West Southeast Moluccas Border Region, since they had the highest average yield each $1.29 \mathrm{t}$ and $1.25 \mathrm{t} \mathrm{ha}^{-1}$, respectively. However the yields obtained in this assessment are still low because the number of productive tillers is also low due to the very small number of seeds used per planting hole, and the effect of legowo 2:1 planting system with a spacing that is too wide actually affects the plant population per hectare.

\section{Acknowledgement}

We express our gratitude to the Senior Researcher of Assessment Institute for Agricultural Technology of Moluccas, Dr. Ir. Janes Berthy Alfons, M.S for guidance and field implementation of upland rice study activities in the border area. We also express our gratitude to all parties in the area of implementation of the activities that have helped so that this study can be carried out properly. Do not forget to thank for all the officials of the Agricultural Research and Development Agency, Ministry of Agriculture for the allocation of costs assessment to border areas in an effort to support food availability.

\section{References}

Anonymous (2018). List of Indonesia's Outer Islands. https://id.wikipedia.org/wiki/list of Indonesia's outer islands. Downloaded in Dec., 162018.

CBS [Central Bureau of Statistic] Moluccas Province. (2015). Moluccas in Figures 2015. Central Bureau of Statistics of Moluccas Province. Ambon.

Gomez, K. A., \& Gomez, A. A. (1995). Statistical Procedures for Agricultural Research. An International Rice Research Institute Book. A Wiley-Interscience Publication. John Wiley \& Sons, USA.

Haryati, Y., \& Liferdi. (2017). Study of Technology Jajar Legowo Super in Supporting Increased Rice Production. Agrin, 21(2), 169-175.

Jamil, A., Satoto, Sasmita, P., Baliadi, Y., Guswara, A., \& Suhama. (2015). Description of New Superior Varieties. Agricultural Research and Development Agency, Ministry of Agriculture. $77 \mathrm{pp}$.

Manurung, J., Armaini, \& Idwar (2017). Adaptation Test of Several Local Upland Rice (Oryza sativa L.) Varieties which Different Groundwater Voltage Conditions in Ultisol Soil Materials. JOM Faperta, 4(1).

Nuryanto, B. (2018). Environmental Management of Rice Crops Through Management of Endemic Components. Agricultural Research Journal, 37(1), 1-8.

https://doi.org/10.21082/jp3.v37n1.2018.p1-8 


\section{Macrothink}

Journal of Agricultural Studies

ISSN 2166-0379 2019, Vol. 7, No. 1

Ralahalu, K. A. (2007). Development Management of Moluccas Province as an Archipelago Province with Wisdom (Culture). One-Day Seminar on the $44^{\text {th }}$ Anniversary and the $1^{\text {st }}$ Graduation Ceremony of the 2007 Pattimura University Ambon, April 16, 2007.

Saylendra, A. (2010). Identification of Fungi Carried by Rice Seeds from Ciruas District, Serang Regency, Banten. Agroecotech Journal, 2(2), 24-27.

Sitinjak, H., \& Idwar. (2015). Response of Various Wetland rice Varieties (Oryza sativa L.) which Planted by Jajar Legowo and Tile System Approach. JOM Faperta, 2(2). https://media.neliti.com/media/publications/188342-ID-none.pdf

Sujitno, E., Fahmi, T., \& Teddy, S. (2011). Adaptation Study on Some Upland Rice Superior Varieties in Lowland Dry Land in Garut Regency. Journal of Assessment and Development of Agricultural Technology, 14(1), 62-69.

Sumarno, \& Hidayat, J. R. (2007). Expansion of Upland Rice Area as an Option to Support National Food Security. Food Crop Science and Technology, 2(1), 26-40.

Supijatno, Chozin, M. A., Soepandie, D., Trikoesoemaningtyas, Junaedi, A., \& Lubis, I. (2012). Evaluation of Water Consumption of Some Rice Genotypes for Potential Efficient Use of Water. J. Argon Indonesia, 40(1), 15-20.

Susanto, A. N., \& Bustaman, S. (2006). Data and Information Land Resources Support Agribusiness Development in the Islands of Moluccas Province. Assessment Institute for Agricultural Technology of Moluccas.

Wahyuni, S. (2008). Results of Upland Rice from Two Different Sources of Seeds. J. Food Crop Agriculture Research, 27(3), 135-140.

Yuniarti, S. (2015). Growth response and yield of upland rice new varieties in Pandeglang Regency, Banten. Proc. Seminar of Indonesian Biodiv. Community, 1(4), 848-851. https://doi.org/10.13057/psnmbi/m010432 


\section{$\triangle$ Macrothink}

Journal of Agricultural Studies

ISSN 2166-0379

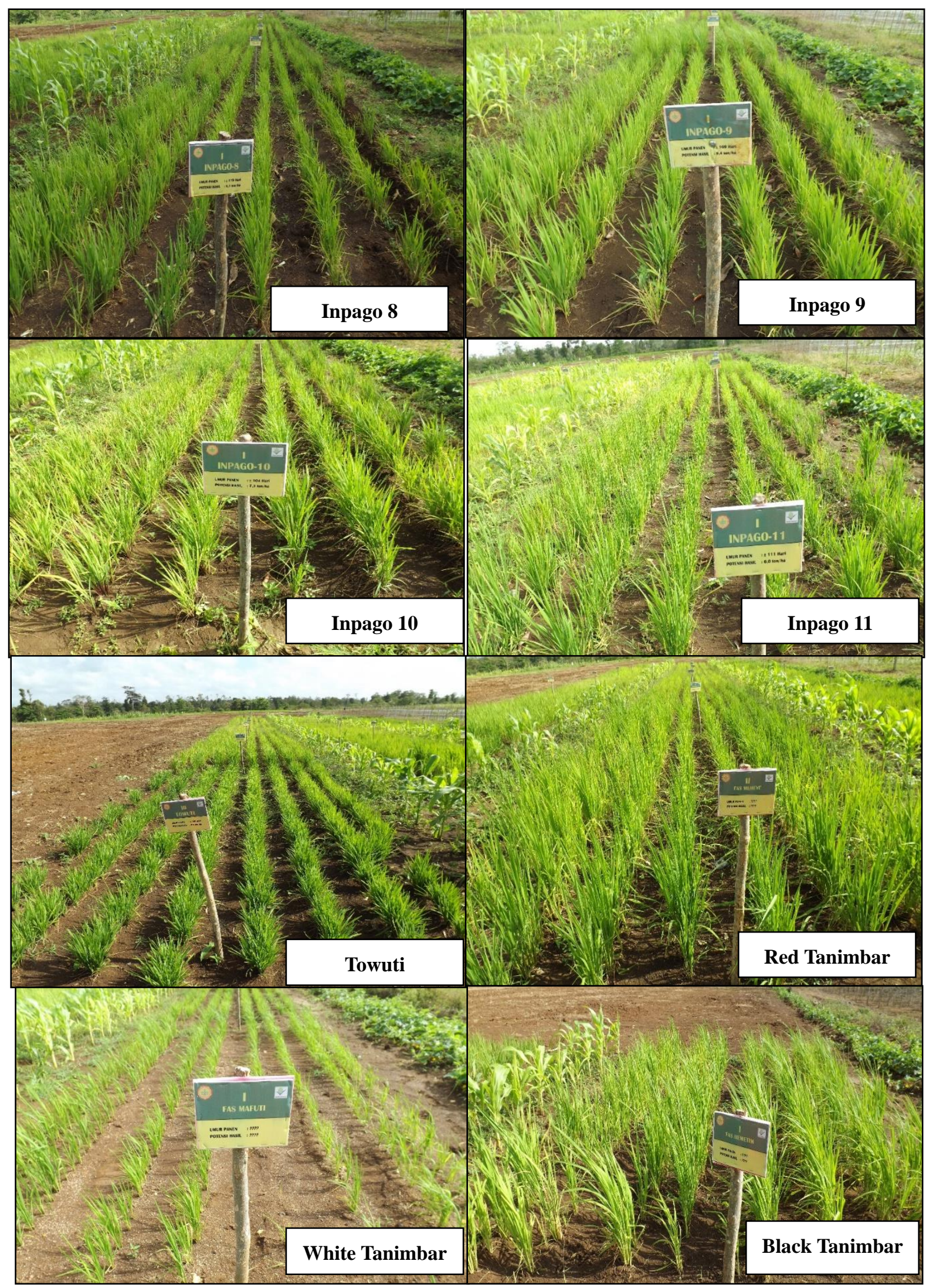

Perfomance of eight upland rice which assessment in the field on vegetative stadium 


\section{Copyright Disclaimer}

Copyright for this article is retained by the author(s), with first publication rights granted to the journal.

This is an open-access article distributed under the terms and conditions of the Creative Commons Attribution license (http://creativecommons.org/licenses/by/4.0/). 